\title{
Liquid water storage in snow and ice in 86 Eastern Alpine basins and its changes from 1970-97 to 1998-2006
}

\author{
Michael KUHN, ${ }^{1}$ Kay HELFRICHT, ${ }^{2}$ Martin ORTNER, ${ }^{3}$ Johannes LANDMANN, ${ }^{4}$ \\ Wolfgang GURGISER ${ }^{1}$ \\ ${ }^{1}$ Institute of Atmospheric and Cryospheric Sciences, University of Innsbruck, Innsbruck, Austria \\ E-mail: michael.kuhn@uibk.ac.at \\ ${ }^{2}$ Institute for Interdisciplinary Mountain Research, Austrian Academy of Sciences, Austria \\ ${ }^{3}$ Central Agency of Meteorology and Geodynamics, Klagenfurt, Austria \\ ${ }^{4}$ Institute of Geography, University of Innsbruck, Innsbruck, Austria
}

\begin{abstract}
The retention and release of liquid water in glacierized basins was modelled with a conceptual, semi-distributed model of the water and ice balance designed for long-term averages with monthly resolution for $100 \mathrm{~m}$ elevation bands. Here we present the components of the liquid water balance of 86 mostly glacierized basins on either side of the main Alpine divide between 10 and $13^{\circ} \mathrm{E}$ in the period 1998-2006 and compare them with the records of 30 basins monitored from 1970 to 1997. Basin average of liquid water retention has maxima in excess of $100 \mathrm{~mm}$ per month in May, often followed by maximum release when the retaining snow matrix melts. Glacier storage peaks in August partly due to ice melt and the ensuing filling of the englacial reservoirs and partly on account of a precipitation maximum. These two components combined to a common maximum of storage in summer in the first period 1970-97 and developed two distinct maxima in the warmer period 1998-2006. A further maximum of liquid water storage that was often found in October is most likely due to a peak in precipitation in the southern part of the study region.
\end{abstract}

KEYWORDS: Alpine water balance, climate change, liquid water storage, meltwater retention

\section{INTRODUCTION}

In Alpine basins, liquid water may be stored in the ground, in vegetation, in snowpack and glaciers, in rivers, lakes and reservoirs, and to a negligible amount in the atmosphere. In this study, we calculate the amount of liquid water storage $(L W S)$ in 86 basins and sub-basins in the Tyrolean Alps between 10 and $13^{\circ} \mathrm{E}$ and 46.5 and $47.5^{\circ}$ North (Fig. 1).

The basis for our modern understanding of the behaviour of water in ice and snow was to a great part laid in the International Hydrological Decade (1965-74). Further, processes like infiltration, saturation and metamorphosis that were studied in laboratory experiments or at the plot scale produced substantial knowledge at the smaller scales (e.g. De Quervain, 1973; Colbeck, 1978; Ambach and others, 1981; Röthlisberger and Lang, 1987; Fountain, 1989; Kattelman and Dozier, 1999). Point measurements of liquid water in snow were made, among others, by Denoth and others (1984). These measurements have recently been revived with novel methods (Techel and Pielmeier, 2011; Eisen and Schweizer, 2014; Koch and others, 2014; Heilig and others, 2015; Schmid and others, 2015), however, again at the point or plot scale.

The work of Stenborg (1970) is an early example of the consideration of LWS at the basin scale as the cause for 'runoff delay' and Tangborn and others (1975) concluded that LWS is 'not negligible'. Reviews by Jansson and others (2003); Verbunt and others (2003) and Hock and others (2005) give further references to recent work, which is generally concerned with limited areas or single basins. Here we attempt to survey the course of LWS characteristics for a large number of basins in two periods of different climate (1970-97 and 1998-2006). Beyond that, we analyse them with respect to the different climatic conditions found in the area of investigation.

\section{DATA AND METHODS}

In order to determine long-term averages of the LWS for each basin we use OEZ, a conceptual, semi-distributed model with monthly resolution and $100 \mathrm{~m}$ elevation bands (Summaries of this model were given in Kuhn, 2000, 2003, more details are given below). We calculate the balance of water in any phase between precipitation $P$, runoff $Q$, evapotranspiration $E$ and storage $S$ at the basin scale. We then model the rain fraction in precipitation and the amount of meltwater produced for each month, compare them with the measured basin runoff and consider the difference to be storage or release of liquid water.

$$
P=Q+E+S
$$

Since $S$ is only known from the glacier inventories as period mean annual value (1970-97 and 1998-2006), the solution of Eqn (1) proceeds from period mean annual values of each term. Runoff data are available from public services and power companies. Evaporation was parameterized according to altitude, vegetation and snow cover (Kuhn, 2000, 2003). Results are in agreement with other authors (e.g. Kaser, 1982; Körner, 1999; De Jong and others, 2002; Braun and others, 2007). It was assumed that, for long-term averages, changes in the storage term are restricted to changes in glacier mass balance. Values of the long-term glacier mass balance were taken from three Austrian glacier inventories (Lambrecht and Kuhn, 2007; Abermann 


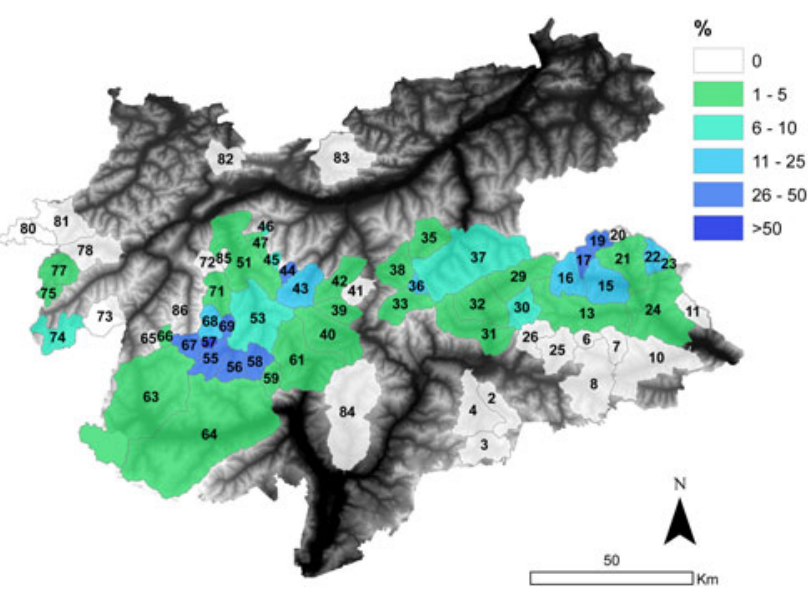

Fig. 1. The basins used in this study. The fraction of the basins covered by glaciers is given in \% of the total basin area by a colour code. Some of the basins are described in Table 1. The grey of the background indicates low elevation with dark shades like Lech Valley in the North-East, the Inn Valley from West to East in the North and the Etsch Valley in the South. The Main Alpine divide runs approximately from basin 65 to 58 to 33 to 20 . Basins 63 and 64 as well as 2-4 are the driest, well screened by high mountains from both North and South. Only sub-basins are entered in this map, some large aggregated basins are mentioned in the text, for example, 34 Mayrhofen, which includes basins 35-37 and 79 Steeg, which includes basins 80 and 81 .

Table 1. Glacier cover, basin area, basin altitude range and annual basin precipitation of selected basins, for the period 1998-2006

\begin{tabular}{llrll}
\hline Basin & $\begin{array}{l}\text { Glacier } \\
\text { cover } \\
\%\end{array}$ & Area & Altitude range & $\begin{array}{l}\text { Annual } \\
\text { precipitation } \\
\end{array}$ \\
& \multicolumn{1}{c}{$\mathrm{km}^{2}$} & $\mathrm{~m}$ & $\mathrm{~mm}$ \\
\hline 57 Vernagt & 74 & 12 & $2600-3600$ & 1900 \\
67 Gepatsch & 39 & 55 & $1800-3500$ & 1720 \\
55 Rofenache & 37 & 98 & $1900-3700$ & 1500 \\
19 Innergschlöß & 35 & 40 & $1600-3600$ & 2620 \\
44 Alpein & 30 & 23 & $2000-3400$ & 1640 \\
46 Kraspes & 8 & 6 & $2000-3000$ & 1550 \\
63 Spondinig* & 3 & 639 & $800-3700$ & 1000 \\
34 Mayrhofen* & 7 & 618 & $600-3500$ & 1850 \\
75 Verwall & 5 & 34 & $1900-3100$ & 2070 \\
3 Pedraces & 0 & 121 & $1300-3100$ & 1210 \\
7 Außervillgraten & 0 & 172 & $1100-2900$ & 1250 \\
79 Steeg & 0 & 242 & $1100-2800$ & 2210 \\
83 Scharnitz & 0 & 203 & $900-2700$ & 1660 \\
\hline
\end{tabular}

Basin numbers refer to Figure 1. Basin 34 Mayrhofen aggregates basins 35-37, 79 Steeg comprises basins 80 and 81 . Basins affected by hydro-electric dams are marked with*.

and others, 2012; Kuhn and others, 2012) and of South Tyrol (Knoll and others, 2009). These inventories supplied DEMs for the years 1969, 1997/98 and 2006, providing constraints on the storage terms $S$ for Period 1 and 2, by calculating the respective glacier volume changes using DEM differencing. Averages of $Q$ were determined from measured values and those of $E$ were estimated for these two periods as well. The resulting value of $P$ is thus the mean of annual basin precipitation over the corresponding period, referred to as 'period mean' in the following.

The period mean annual value of basin precipitation was distributed over all months of the year, proportional to precipitation period mean monthly values from reference stations. The undercatch caused by wind and snow (Dingman, 2015) was corrected according to Sevruk (1983). Basin precipitation was then distributed with altitude with monthly values of precipitation gradients $(d P / d z(m o))$ and adjusted in the successive approximations of the model as $P(m o)$ so that the basin value of $P$ was preserved. With measured values of $Q(m o)$, parameterized evaporation $E(m o)$, monthly storage $S(\mathrm{mo})$ was determined by Eqn (1).

Temperature $T(m o, z)$ was determined using $T(m o) r e f$ from reference stations in the valley and converted to $T$ $(m o, z)$ with lapse rates taken from the HISTALP dataset (Chimani and others, 2012) for 12 regional groups of basins. Temperature $T(m o, z)$ is required to distinguish between rain and snow, and to calculate potential melting using degree-day factors $D D F(\mathrm{mo})$. The choice of $D D F$ (mo) and $d P / d z(m o)$ is not well-constrained; their interdependence increases the uncertainty of the model as will be described below. Finally, snow is redistributed by wind drift and avalanches once it is deposited, giving glaciers higher accumulation than ice-free ground as is observed in nature (Kuhn, 2003; Helfricht and others, 2014). This redistribution is accomplished in the model by moving snow from ice free to glacier areas using constant factors for each basin, it is constrained by the specific glacier mass balance and its change with altitude as derived from the DEMs of the glacier inventories.

LWS is then derived from the balance of the liquid parts of Eqn (1), reduced by evaporation

$$
L W S=R+M-E-Q
$$

The magnitude of $L W S$ is generally smaller than the runoff $Q$, meltwater $M$ and rain $R$, and it is the small difference of possibly large quantities. This makes it especially important to consider its uncertainty.

\section{Uncertainty}

Basically, uncertainty in this investigation has four components: uncertain data input, an imperfect model, uncertain parameterization and the uncertainty whether liquid water is stored in the ground or in snow and ice. As a reference text we recommend the book of Gupta (2012) and recent evaluations of uncertainty in hydrological modelling (e.g. Gupta and others, 1998; Zappa and others, 2003; Addor and others, 2014; Huss and others, 2014).

The uncertainty of the data input is difficult to estimate. Monthly runoff values with peak discharge may be off by up to $10 \%$ when moving bed load alters the rating curve, but in large basins and with long-term averages, uncertainty will be reduced. Precipitation and evaporation are known to suffer from measurement errors (Sevruk, 1983; Brutsaert, 2005; Hendriks, 2010; Dingman, 2015). Geodetic determination of storage change in glaciers based on DEM differencing may be better than $\pm 150 \mathrm{~mm}$ (Abermann and others, 2010; Bollmann and others, 2011); conventional glacier mass balances may have errors of 100-200 mm (e.g. Andreassen and others, 2015). The contribution of these uncertainty values to overall uncertainty is distinctly reduced by the ratio between glacierized to total area. For the uncertainty of each of these data sources there exists a certain consensus in the scientific community, but that cannot be taken as a basis for a meaningful statistical analysis (Nuzzo, 2014). 
Our model is not an operational model and is not used as a predictive model in this study. Its purpose is to determine the evolution of the Alpine water balance as a response to long-term climatic changes. It does not lend itself to a rigorous validation in this context. It is based on two basin mean, period mean annual values of $S, Q, E$ and $P$ like $S$ (1970-97) and $S$ (1998-2006), which excludes the application of a leave-one-out validation. It is calibrated with measured period means of monthly basin runoff, calculated period means of annual storage change based on three glacier inventories and period means of monthly, parameterized evaporation. It is most accurate in high-altitude basins and in basins with large relative ice cover and we expect it to be least accurate in low altitude, vegetated areas.

A desirable cross validation of this model with direct glaciological measurements suffers from the lack of any records of basin-wide LWS determined with other methods to compare with.

The model was calibrated for each basin to meet the objectives of reproducing the measured period mean monthly runoff within $\pm 20 \mathrm{~mm}$ and reproducing the period mean of annual glacier mass balance, given by three glacier inventories, within $\pm 50 \mathrm{~mm}$.

There are at least two cases of equifinality where similar quality of optimization can be reached with several possible combinations of parameters, namely the interdependence of $d P / d z$ and $d T / d z$ in creating accumulation at a given height and that of $d T / d z$ and $D D F$ in melting that amount: smaller temperature lapse rates require lower $D D F s$ to melt a given amount of snow.

$$
\begin{aligned}
& \text { Accumulation }=P\left(z_{0}\right)+(d P / d z) \Delta z \\
& \text { Ablation }=\left(T\left(z_{\mathrm{o}}\right)+(d T / d z) \Delta z\right) D D F
\end{aligned}
$$

This ambiguity was constrained by limiting DDFs between 4 $\mathrm{mm} / \mathrm{DD}$ (mm w.e. per degree-day) for winter snow and $8 \mathrm{~mm} /$ DD for bare glacier ice and by assuming that $d P / d z$ should be higher with advective precipitation prevailing in winter than with convective precipitation prevailing in summer. Regional values of $d T / d z$ given in the HISTALP dataset were used (Chimani and others, 2012). Given these constraints we decided that a Monte Carlo Simulation of LWS determination, which is the central topic of this investigation, would at least give a fair indication of uncertainty. The Monte Carlo Simulation was set up for one basin, that of 12 Lienz
Isel 1970-97, results are given in Figure 2. Assuming normal distribution of all input parameters we used the following standard deviations: $0.25^{\circ} \mathrm{C}$ for the reference temperature, $5 \%$ for reference precipitation, $0.05^{\circ} \mathrm{C} 100 \mathrm{~m}^{-1}$ for lapse rate, $2 \%(100 \mathrm{~m})^{-1}$ for the altitudinal change of precipitation and 0.1 for the redistribution factor of snow. This resulted in maximum values of the standard deviation of LWS of about $\pm 30 \mathrm{~mm}$ that are reached in May and July. This is about one third of the mean LWS in these months, but little compared with precipitation and runoff. It should be kept in mind that a Monte Carlo simulation is a strictly statistical evaluation in which individual input parameters are assumed to have a normal probability density function and are varied independently, for example, deviations of temperature are not correlated with deviations of precipitation.

\section{RESULTS AND DISCUSSION}

Monthly values of the four components of the water balance plus $L W S$ have been calculated for all basins, examples are given in Figure 3. Physiographic characteristics are presented in Table 1. Monthly values of $L W S$, solid storage and cumulative w.e. of solid storage are shown in Table 2, all expressed in mm w.e. The basins 19 Innergsch/öß and 55 Rofenache are of the glacial type and show maximum melt and runoff in July, produced by glacier melt. The basins 79 Steeg and 3 Pedraces, with runoff maxima produced by snowmelt in May or June, are of the nival type. Precipitation is abundant in all four examples, with maxima in July and August reflecting convective activity. Innergsch/öß, Rofenache and Pedraces show secondary maxima in October and November, which are typical for Mediterranean influence, and are observed up to the main Alpine divide. Evaporation plays a subordinate role in these three basins, with higher values at the lower altitude of 79 Steeg.

The basins 63 Spondinig and 34 Mayrhofen listed in Table 2 contain hydropower reservoirs, which store water in the summer months and release it for power production in the winter. Although both basins have large areas this activity is evident in extreme values and amplitudes of $L W S$.

Glacier changes from the first to the second period were considerable. Arithmetic means of mean annual specific mass balance have been derived from DEM differencing for glaciers in the 28 glacierized basins, for which data exist in both periods. The mean annual specific glacier

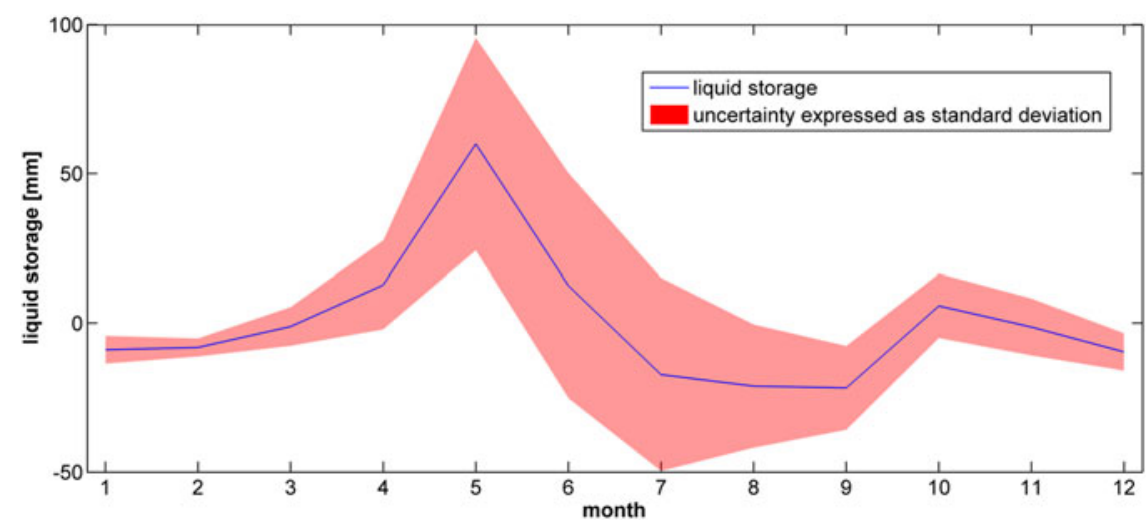

Fig. 2. Uncertainty of the determination of the LWS expressed as one standard deviation from the monthly mean derived from a Monte Carlo Simulation. Valid for the basin 12 Lienz Isel, which includes basins 13-24 in Figure 1, for the years 1970-97. This basin has an area of 1197 $\mathrm{km}^{2}$ extending from 600 to $3700 \mathrm{~m}$, is to $5 \%$ glacierized and has precipitation maxima in November and August. 

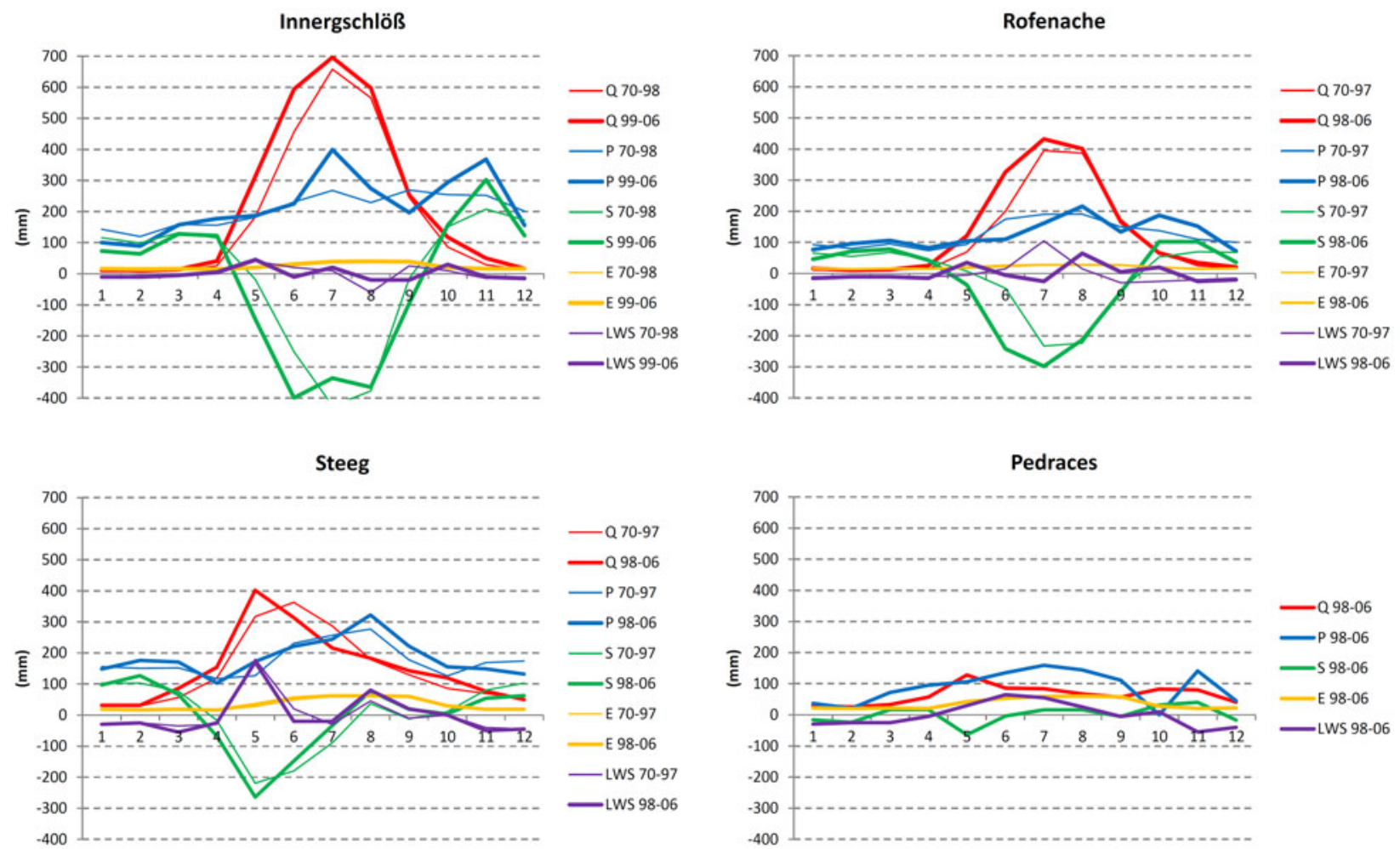

Fig. 3. Examples of the components of the water balance in the two periods, period mean monthly values in mm w.e.. $Q$ is runoff, $P$ precipitation, $S$ storage, $E$ evaporation and $L W S$ liquid water storage. The basin of 55 Rofenache is high (Table 1) and relatively dry (Table 2), 19 Innergschlöß is high and wet, 79 Steeg is relatively low and wet, while 3 Pedraces is low and dry. Basin numbers are those given in Figure 1 where 79 Steeg comprises basins 80 and 81 . Hydrological years are indicated by the calendar year in which they end, for example, 1970 refers to October 1969-September 1970. Faint lines refer to the first period, heavy lines to the second.

Table 2. Averages 1998-2006 of monthly LWS and monthly solid storage of snow and ice in the basins listed in Table 1, each in mm w.e. per month

\begin{tabular}{|c|c|c|c|c|c|c|c|c|c|c|c|c|}
\hline & October & November & December & January & February & March & April & May & June & July & August & Septem \\
\hline \multicolumn{13}{|l|}{57 Vernagt } \\
\hline Liquid storage & 20 & -5 & -5 & -5 & -5 & -5 & -5 & -35 & -40 & 85 & 60 & -60 \\
\hline Solid storage & 124 & 144 & 62 & 67 & 88 & 98 & 68 & 26 & -187 & -550 & -517 & -54 \\
\hline Solid sum & 124 & 268 & 330 & 397 & 486 & 584 & 652 & 678 & 491 & -58 & -576 & -630 \\
\hline \multicolumn{13}{|l|}{67 Gepatsch } \\
\hline Liquid storage & 10 & -15 & -15 & -10 & -5 & -5 & -10 & 45 & 15 & -40 & 20 & 10 \\
\hline Solid storage & 75 & 149 & 67 & 72 & 85 & 92 & 79 & -74 & -254 & -265 & -227 & -32 \\
\hline Solid sum & 75 & 223 & 290 & 363 & 448 & 540 & 619 & 546 & 292 & 27 & -199 & -232 \\
\hline \multicolumn{13}{|l|}{55 Rofenache } \\
\hline Liquid storage & 20 & -25 & -20 & -15 & -10 & -10 & -15 & 35 & -5 & -25 & 65 & 5 \\
\hline Solid storage & 82 & 127 & 56 & 61 & 81 & 88 & 58 & -71 & -237 & -273 & -278 & -65 \\
\hline Solid sum & 82 & 208 & 264 & 325 & 406 & 494 & 552 & 481 & 244 & -29 & -307 & -372 \\
\hline \multicolumn{13}{|l|}{19 Innergschlöß } \\
\hline Liquid storage & 30 & -10 & -15 & -10 & -10 & -5 & 5 & 45 & -10 & 20 & -20 & -20 \\
\hline Solid storage & 125 & 312 & 138 & 83 & 74 & 133 & 117 & -192 & -389 & -356 & -345 & -75 \\
\hline Solid sum & 125 & 437 & 575 & 658 & 732 & 864 & 981 & 789 & 400 & 43 & -301 & -376 \\
\hline \multicolumn{13}{|l|}{44 Alpein } \\
\hline Liquid storage & 30 & 5 & -5 & -5 & -5 & 0 & 5 & 50 & -20 & -30 & -10 & -15 \\
\hline Solid storage & 47 & 116 & 56 & 54 & 70 & 87 & 94 & -102 & -182 & -225 & -206 & -27 \\
\hline Solid sum & 47 & 163 & 220 & 274 & 344 & 431 & 525 & 423 & 241 & 16 & -190 & -218 \\
\hline Liquid storage & 20 & -15 & -15 & -10 & -10 & -5 & 10 & 110 & 15 & -30 & -50 & -20 \\
\hline Solid storage & 36 & 111 & 53 & 50 & 65 & 82 & 90 & -161 & -206 & -111 & -54 & -10 \\
\hline Solid sum & 36 & 148 & 201 & 251 & 316 & 397 & 487 & 327 & 120 & 9 & -45 & -55 \\
\hline \multicolumn{13}{|l|}{63 Spondinig } \\
\hline Liquid storage & 25 & -35 & -45 & -50 & -45 & -35 & -10 & 75 & 50 & 30 & 35 & 5 \\
\hline Solid storage & 12 & 66 & 21 & 26 & 24 & 27 & 2 & -110 & -62 & -23 & -18 & -5 \\
\hline Solid sum & 12 & 77 & 98 & 124 & 148 & 175 & 177 & 68 & 6 & -17 & -35 & -40 \\
\hline \multicolumn{13}{|l|}{34 Mayrhofen } \\
\hline Liquid storage & 20 & -65 & -75 & -70 & -70 & -60 & -10 & 150 & 80 & 70 & 30 & 0 \\
\hline
\end{tabular}


Table 2. (Cont.)

\begin{tabular}{|c|c|c|c|c|c|c|c|c|c|c|c|c|}
\hline & October & November & December & January & February & March & April & May & June & July & August & September \\
\hline Solid storage & 39 & 130 & 64 & 74 & 82 & 95 & 53 & -216 & -171 & -108 & -70 & -5 \\
\hline Solid sum & 39 & 169 & 234 & 308 & 391 & 485 & 538 & 322 & 152 & 44 & -26 & -30 \\
\hline \multicolumn{13}{|l|}{75 Verwall } \\
\hline Liquid storage & 20 & -30 & -25 & -20 & -15 & -10 & -20 & 50 & 35 & -50 & 70 & -5 \\
\hline Solid storage & 28 & 125 & 85 & 104 & 130 & 105 & 66 & -184 & -326 & -100 & -49 & -9 \\
\hline Solid sum & 28 & 153 & 238 & 341 & 471 & 576 & 642 & 458 & 132 & 32 & -17 & -26 \\
\hline \multicolumn{13}{|l|}{3 Pedraces } \\
\hline Liquid storage & 10 & -55 & -40 & -30 & -25 & -25 & -5 & 30 & 65 & 55 & 25 & -5 \\
\hline Solid storage & 22 & 95 & 23 & 14 & 1 & 42 & 22 & -94 & -69 & -39 & -9 & 0 \\
\hline Solid sum & 22 & 117 & 140 & 154 & 155 & 197 & 218 & 124 & 55 & 16 & 7 & 8 \\
\hline \multicolumn{13}{|l|}{79 Steeg } \\
\hline Liquid storage & 0 & -50 & -45 & -30 & -25 & -55 & -25 & 170 & -20 & -20 & 80 & 20 \\
\hline Solid storage & 4 & 104 & 108 & 127 & 152 & 121 & -42 & -434 & -128 & -14 & -3 & -1 \\
\hline Solid sum & 4 & 108 & 216 & 343 & 495 & 616 & 574 & 140 & 12 & -2 & -5 & -6 \\
\hline \multicolumn{13}{|l|}{83 Scharnitz } \\
\hline Liquid storage & -30 & -45 & -40 & -40 & -30 & -40 & 10 & 180 & 50 & -10 & 25 & -30 \\
\hline Solid storage & 3 & 73 & 66 & 78 & 101 & 89 & -27 & -266 & -95 & -19 & -2 & 0 \\
\hline Solid sum & 3 & 76 & 142 & 220 & 321 & 410 & 383 & 117 & 22 & 3 & 2 & 1 \\
\hline
\end{tabular}

Storage values given here are derived from the basin water balance (Eqn (1)) and are annual basin means. For example, solid storage in February includes changes of the snow cover in the entire basin. Values restricted to the glacier surface, i.e. the annual mean specific glacier mass balance, are summarized in Table 3 .

Table 3. Mean values of summer temperature $T$ (June, July, August) and mean annual precipitation $P$ at Obergurgl $\left(11^{\circ} 01^{\prime} 30^{\prime \prime} \mathrm{E}, 46^{\circ} 52^{\prime}\right.$ $03^{\prime \prime} \mathrm{N}, 1930 \mathrm{~m}$ a.s.I.) and arithmetic means of mean specific annual mass balance of the 28 glacierized basins, for which data exist in both periods

\begin{tabular}{llll}
\hline & $\begin{array}{l}\mathrm{T}(J, J, A) \\
{ }^{\circ} \mathrm{C}\end{array}$ & $\begin{array}{l}\mathrm{P} \\
\mathrm{mm}\end{array}$ & $\begin{array}{l}\mathrm{B} \\
\mathrm{mm} \mathrm{w.e.} \mathrm{a}^{-1}\end{array}$ \\
\hline $1970-97$ & 10.3 & 820 & -560 \\
$1998-2006$ & 11.3 & 930 & -1170 \\
\hline
\end{tabular}

mass balance changed from $-560 \mathrm{~mm}$ w.e. $\mathrm{a}^{-1}$ in the first period to $-1170 \mathrm{~mm}$ w.e. $\mathrm{a}^{-1}$ in the second period. These results are compared with summer temperatures und annual precipitation in Table 3. The sensitivity of the glacier mass balance to climate changes is in good agreement with results presented by Kuhn (2003).
Snowmelt causes an early increase in runoff and contributes to a first peak in $L W S$, which is particularly well developed in the basin of 79 Steeg. Secondary peaks in LWS in summer and fall appear to coincide with peaks in precipitation. In fall and winter, changes of $L W S$ feed the base flow at a rate that is obviously influenced by basin altitude. In Table 2, monthly values of LWS are presented together with solid storage including release by ice melt, all expressed as basin averages. Figure 4 presents two examples of monthly LWS with a pronounced change from one summer peak in the first period to two in the second. The release of water between the two peaks feeds the summer base flow. Figure 5 shows that the trend from prevailing single summer peaks of $L W S$ to double peaks is indeed widespread.

In Figure 4 and Table 2 we observe frequent release of LWS in the months following the first LWS peak, which may have several causes. One is a release of the storage in the snow pack that was filled with meltwater in May.
Verwall

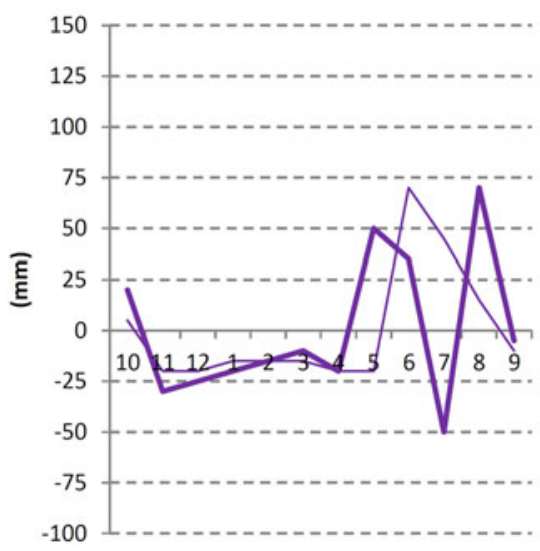

Rofenache

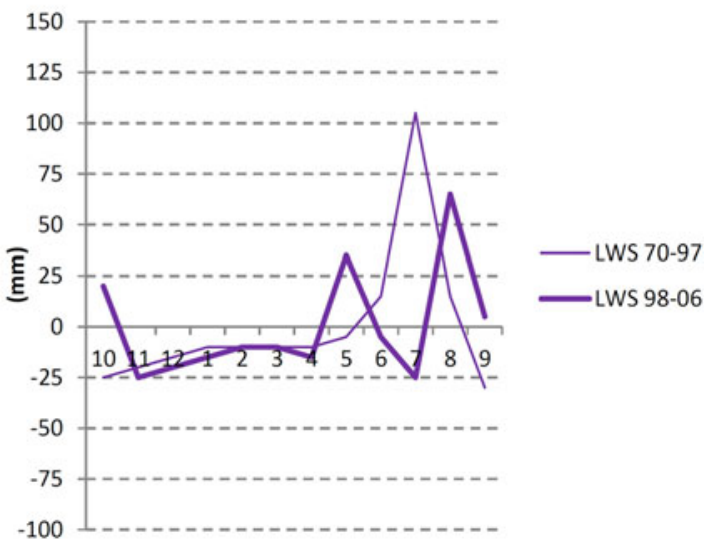

Fig. 4. LWS in the basins of 75 Verwall and 55 Rofenache. Note the change from one maximum in June or July to two maxima in May and August, the first due to earlier snow melt and the second primarily due to the precipitation maximum in August. Basin characteristics are given in Table 1. 


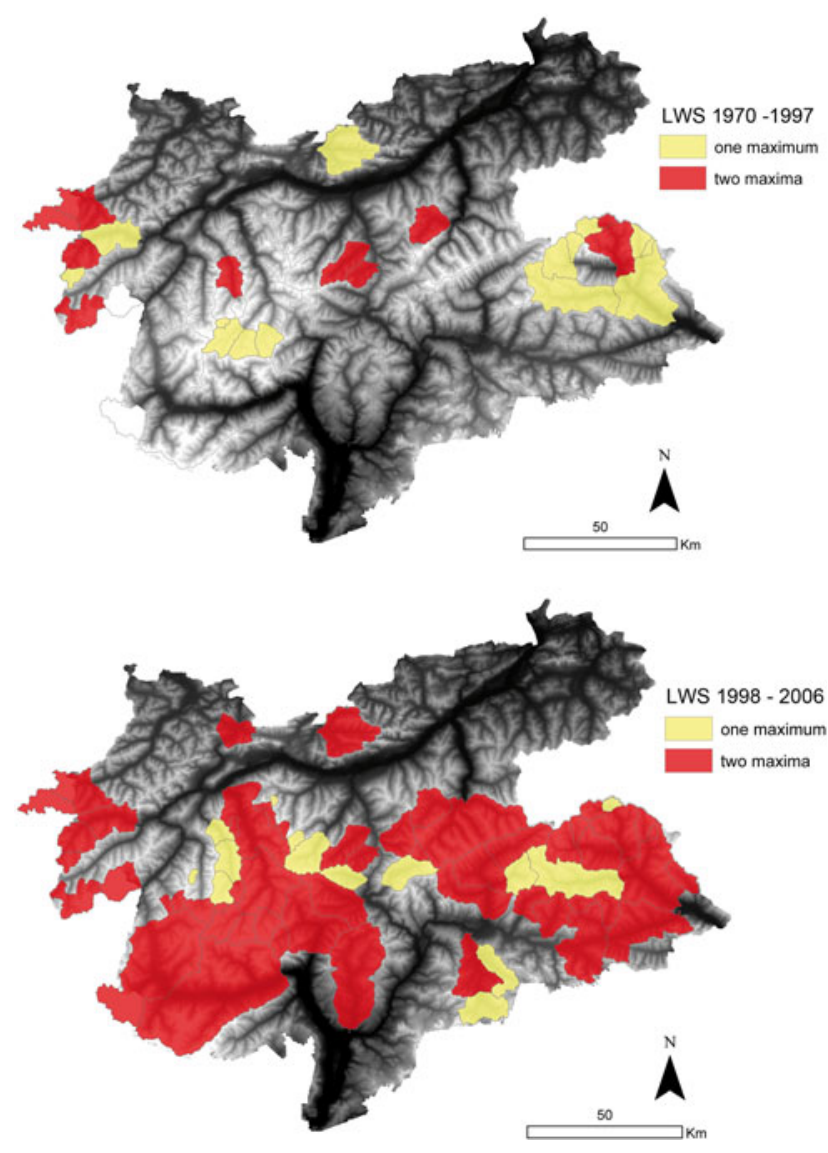

Fig. 5. The appearance of maxima of $L W S$ in the summer months. Yellow colour indicates one maximum (usually in July), red indicates two maxima, usually in May and August. This obvious shift from one maximum in the first period, where basin-wide snowmelt and summer rains nearly coincided, to two in the second period, is due to earlier snowmelt in recent years combined with a minor increase in late summer precipitation.
Figure 6 shows that from May to July, snow w.e., and thereby storage space within the snow pack, is drastically diminished in the altitude bands between 2800 and $3100 \mathrm{~m}$. Meltwater stored in the snow since May slowly drains during summer from the remaining snow pack, firn body and bare ground, like base flow in winter. It should be noted that in the active time of the water cycle from May to October, all transient hydrological reservoirs of the basin are being refilled and release water at the same time. These processes have been referred to in various studies. De Quervain (1973) noted that 'a considerable amount of free water may exist in a transient state during and following a melting period or rainstorm'. Fountain (1989) found a rise of water storage in April and a release in October on South Cascade Glacier, which seems typical for the glaciers in the Alpine area as well. Verbunt and others (2003) give the change of water balance components with altitude for three Alpine catchments and Jansson and others (2003) state that the annual course of $L W S$ is governed by seasonal snow, water in firn and en- and subglacial water. They show the seasonal change of storage and release of water in glaciers of various climatic conditions. Further references are given in the chapter on Glacial Hydrology in Cuffey and Paterson (2010).

Next, we present how much of the LWS is in each transient hydrological reservoir. For snow, Heilig and others (2015) give $5 \%$ by volume as a frequently appropriate upper limit of $L W S$. The cumulative value of the w.e. of the snow pack, given in the third line for each basin in Table 2, provides an upper bound on the snow storage. For example, 75 Verwall in the month of May has a liquid storage of $50 \mathrm{~mm}$ w.e., a large part of which may be accommodated in the snow pack of $458 \mathrm{~mm}$ w.e.. In the unglacierized basin 79 Steeg, again in May, the liquid storage of $170 \mathrm{~mm}$ does not fit into $140 \mathrm{~mm}$ w.e. of the snowpack so that a considerable amount must be stored as ground water as no other transient storage reservoirs exist at the surface.

Finally, we address the question of how much the presence of glaciers influences the seasonal course and the amplitude of

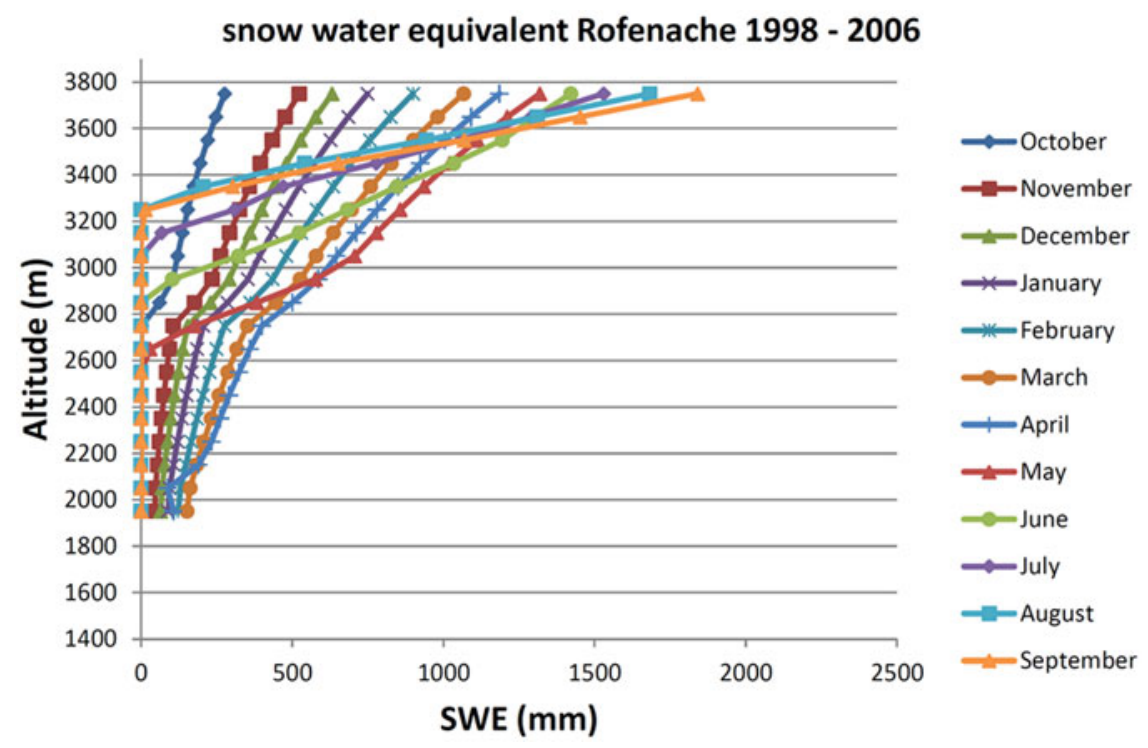

Fig. 6. Evolution of the snow w.e. in the basin of 55 Rofenache, mean values for the period 1998-2006. In the dark blue profile of monthly net accumulation in October, appreciable accumulation starts from $2800 \mathrm{~m}$ a.s.l. upwards. The snow w.e. increases at all elevation bands throughout the accumulation season till April (blue crosses). The snow line retreats to $2900 \mathrm{~m}$ in May-June (brown and green profiles) and reaches the equilibrium line altitude (ELA) at $3250 \mathrm{~m}$ in September with maximum altitudinal gradients. Each of the profiles leads to an upper bound for liquid water storage. 
LWS. From Tables 1 and 2 we find that higher maxima of monthly LWS appear in low elevation, unglacierized basins, which reach altitudes of little more than $2700 \mathrm{~m}$, while areas with large glacier covers go up to $\sim 3700 \mathrm{~m}$. This suggests that for the variation of $L W S$, the altitude range as given for example, in Table 1, is more important than glacier cover. The basin 57 Vernagt with an altitude range 2600-3600 m and $74 \%$ ice cover is an exception in Table 2 with peak LWS in July and August. In other basins, an indication of increased englacial storage in August was not found.

\section{CONCLUSIONS AND OUTLOOK}

Using a semi-distributed hydro-meteorological model we determined monthly values of the components of the water balance and of LWS in glacierized and ice-free basins for two climatically different periods. A Monte Carlo simulation of LWS in one large basin indicated a standard deviation of $30 \mathrm{~mm}$ w.e. in May and less in other months. LWS has a pronounced seasonal variation that is similar in all basins. We found a change from a single summer peak of LWS in the first period 1970-97 to a double peak in May and August. We believe that it is due to higher temperatures, reduced snow cover and earlier melt in the second period 19982006, separating the spring maximum from the peak in August that may be caused by peak precipitation. We found that a basic condition for an increase in LWS is the supply of liquid water (either meltwater or rain), and we propose that the first LWS peak is supplied by the melting of winter snow. The summer peak or peaks (see Fig. 3, Innergsch/öß) are due to water supply from rainstorms leading to an increase in the amount of water stored in glaciers such as in cavities, channels and crevasses or in subglacial sediments in the summer months.

The single peak in LWS in the first period may be explained in view of climate conditions at that time. In the years from 1965 to 1981, summer temperatures were lower; summer snow falls were more frequent so that minor glacier advances were observed at $\sim 75 \%$ of Alpine glaciers. This meant more snow accumulation and later onset of melting that shifted the first peak of $L W S$ to a later point in time, at the same time enlarging the second peak so that in many cases they grew together.

Typically, we observed release of water in June and July and believe that it is the slow draining of the spring meltwater peak from all storage compartments and the marked reduction of storage capacity in the waning snowpack. We were not able to separate the effects of glacier cover of a basin from that of its altitude when we tried to distinguish glacierized from ice-free basins.

The modelled snow cover may be validated by remote sensing data such as delivered by MODIS (ModerateResolution Imaging Spectroradiometer). However, MODIS records are available only for a limited time of the second period since the year 2000. Moreover, its areal snow cover product does not verify in any way the modelled values of snow w.e. We intend to test the period mean values of this model with the results of MODIS for the period from 2006 to a possible new glacier inventory. As a continuation of the present study we plan to resolve annual values of the water balance using meteorological records and records of annual glacier mass balances from up to ten glaciers in the greater area of investigation.

\section{ACKNOWLEDGEMENTS}

This paper was supported by the Autonomous Province of Bozen/Bolzano, Abt. 40 with Fördervertrag Nr. 29/40.3 (Eis und Wasser in Tirol, Folgen des Klimawandels) and by the University of Innsbruck. The input by Marc Olefs (now at Zentralanstalt für Meteorologie und Geophysik, Vienna) and Lukas Rastner (now at Hydrographic Office Bolzano) to the early phase of this project is highly appreciated. We thank the Scientific Editor Tómas Jóhannesson and the anonymous referees for their valuable comments and encouragement.

\section{REFERENCES}

Abermann J, Fischer A, Lambrecht A and Geist T (2010) On the potential of very high-resolution repeat DEMs in glacial and periglacial environments. Cryosphere, 4, 53-65

Abermann J and 5 others (2012) A new ALS glacier inventory of North Tyrol, Austria, for 2006. Zeit. Glet. Glazialgeol., 43/44 (2009/10), 109-119

Addor $\mathrm{N}$ and 5 others (2014) Robust changes and sources of uncertainty in the projected hydrological regimes of Swiss catchments. Water Res. Res., 50, 7541-7562

Ambach W, Blumthaler M and Kirchlechner P (1981) Application of the gravity flow theory to the percolation of melt water through firn. J. Glaciol., 27(95), 67-75

Andreassen LM, Elvehoy H, Kjollmoen B and Engeset RV (2015) Glaciological and geodetic mass balance of ten long-term glaciers in Norway. Cryosph. Discuss, 9, 6581-6626 (doi: 10.5194/tcd-9-6581-2015)

Bollmann E, Sailer R, Briese C, Stötter J and Fritzmann P (2011) Potential of airborne laser scanning for geomorphologic feature and process detection and quantification in high alpine mountains. Zeit. Geomorphol. Supp., 55, 83-104.

Braun LN, Escher-Vetter E, Siebers M and Weber M (2007) Water balance of the highly glaciated Vernagt basin, Ötztal Alps. In Psenner R and Lackner R eds, Alpine space - man and environment, Vol. 3, The Water Balance of the Alps. Innsbruck University Press, Innsbruck, 33-42. ISBN 978-3-902571-33-5

Brutsaert W (2005) Hydrology. Cambridge University Press, Cambridge, 605 pp.

Chimani B, Matulla C, Böhm R and Hofstätter M (2012) A new high resolution absolute temperature grid for the greater Alpine region back to 1780, Int. J. Climatol. 33(9), (doi: 10.1002/joc.3574)

Colbeck SC (1978) The physical aspects of water flow through snow. Adv. Hydrosci., 11, 165-206

Cuffey KM and Paterson WSB (2010) The physics of glaciers. Elsevier, Amsterdam, $693 \mathrm{pp}$

De Jong C, List FK and Ergenzinger PJ (2002) Experimental hydrological analyses in the Dischma based on daily and seasonal evaporation. Nordic Hydrol., 33(1), 1-14

Denoth A and 6 others (1984) A comparative study of instruments for measuring the liquid water content of snow. J. Appl. Phys., 56, 2154-2160

de Quervain MR (1973) Snow structure, heat, and mass flux through snow. IAHS-AISH Publication No. 107, Vol. I, 203-226

Dingman SL (2015) Physical Hydrology, 3rd edn. Waveland Press, Long Grove, IL, 643 pp

Eisen $\mathrm{O}$ and Schweizer J (2014) Assessing approaches for determination of liquid water in snow. Eos, 95(36), 328

Fountain AG (1989) The storage of water in, and hydraulic properties of, the firn of South Cascade Glacier, Washington State, USA. Ann. Glaciol. 13, 69-76

Gupta SV (2012) Measurement uncertainties. Springer, Berlin, Heidelberg, $321 \mathrm{pp}$

Gupta HV, Sorooshian S and Yapo PO (1998) Toward improved calibration of hydrologic models: multiple and noncommensurable measures of information. Water Res. Res., 34(4), 751-763 
Heilig A and 6 others (2015) Seasonal and diurnal cycles of liquid water in snow - measurements and modeling. J. Geophys. Res. Earth Surf. Sci., 120, 2139-2154 (doi: 10.1002/2015JF003593)

Helfricht K, Schöber J, Schneider K, Sailer R and Kuhn M (2014) Interannual persistence of the seasonal snow cover in a glacierized catchment. J. Glaciol., 60 (223), 889-904 (doi: 10.3189/ 2014JoG13J197)

Hendriks MR (2010) Introduction to physical hydrology. Oxford University Press, Oxford, 331 pp

Hock R, Jansson P and Braun LN (2005) Modelling the response of mountain glacier discharge to climate warming. In Huber UM, Bugmann HKM and Reasoner MA, eds. Global change in mountain regions, Springer, Dordrecht, 243-252

Huss M, Zemp M, Joerg P and Salzmann N (2014) High uncertainty in 21 st century runoff projections from glacierized basins. J. Hydrol., 510, 35-48

Jansson P, Hock R and Schneider T (2003) The concept of glacier storage: a review. J. Hydrol., 282, 116-129

Kaser G (1982) Measurement of evaporation from snow. Arch. Meteorol. Geophys. Bioclimatol. Ser. B, 30(4), 333-340

Kattelman R and Dozier J (1999) Observations of snow pack ripening in the Sierra Nevada, California, USA. J. Glaciol., 45(151), 409-416

Koch F, Prasch M, Schmid L, Schweizer J and Mauser W (2014) Measuring liquid water content with low-cost GPS receivers. Sensors 14, 20975-20999 (doi: 10.3390/s141120975)

Körner C (1999) Alpine plant life - functional plant ecology in high mountain ecosystems. Springer, Berlin, p. 338

Knoll C, Kerschner H and Abermann J (2009) Development of area, altitude and volume of South Tyrolean glaciers since the Little Ice Age maximum. Zeit. Glet. Glazialgeol., 42/1(2008), $19-36$

Kuhn M (2000) Verification of a hydrometeorological model of glacierized basins. Ann. Glaciol., 31, 15-18
Kuhn M (2003) Redistribution of snow and glacier mass balance from a hydrometeorological model. J. Hydrol., 282, 95-103

Kuhn M, Lambrecht A, Abermann J, Patzelt G and Gross G (2012) Austrian glaciers 1998 and 1969: area and volume changes. Zeit. Glet. Glazialgeol., 43/44 (2009/10), 3-107

Lambrecht A and Kuhn M (2007) Glacier changes in the Austrian Alps during the last three decades, derived from the new Austrian glacier inventory. Ann. Glaciol., 46, 177-184

Nuzzo R (2014) Statistical errors. Nature, 506, 150-152

Röthlisberger $\mathrm{H}$ and Lang $\mathrm{H}$ (1987) Glacial hydrology. In Gurnell AM and Clark MJ, eds. Glacio-fluvial sediment transfer, John Wiley, Somerset, NJ, 207-284

Schmid L and 6 others (2015) A novel sensor combination (upGPRGPS) to continuously and nondestructively derive snow cover properties. Geophys. Res. Lett. 42, 3397-3405 (doi: 10.1002/ 2015GL063732)

Sevruk B (1983) Correction of measured precipitation in the Alps using the water equivalent of new snow. Nordic Hydrol., 14(2), 49-58

Stenborg T (1970) Delay of runoff from a glacier basin. Geogr. Ann. Ser. A, 52(1), 1-30

Tangborn WV, Krimmel RM and Meier MF (1975) A comparison of glacier mass balance by glaciological, hydrological and mapping methods, South Cascade Glacier, Washington. IAHS-AISH Publication No. 104, 185-196

Techel F and Pielmeier C (2011) Point observations of liquid water content in wet snow - investigating methodical, spatial and temporal aspects. Cryosphere, 5, 405-418 (doi: 10.5194/tc-5-405-2011)

Verbunt $\mathrm{M}$ and 5 others (2003) The hydrological role of snow and glaciers in alpine river basins and their distributed modelling. J. Hydrol., 282, 36-55 (doi: 10.1016/S0022-1694(03)00251-8)

Zappa M, Pos F, Strasser U, Warmerdam P and Gurtz J (2003) Seasonal water balance of an alpine catchment as evaluated by different methods for spatially distributed snow melt modelling. Nordic Hydrol., 34(3), 179-202 